\title{
Pengaruh Motivasi Kerja terhadap Kinerja Pegawai PT. Pos Indonesia (Persero) Bandar Lampung
}

\author{
Husna Purnama ${ }^{1 *}$, Meilinda Safitri ${ }^{1}$, Denny Junizar ${ }^{1}$ \\ ${ }^{1}$ Universitas Sang Bumi Ruwa Jurai \\ *Correspondence : husnapurnama@fe.saburai.ac.id
}

\begin{abstract}
Abstrak.
Tujuan penelitian untuk mengetahui apakah motivasi kerja berpengaruh terhadap kinerja karyawan PT. Pos Indonesia (Persero) Bandar Lampung. Objek penelitian ini adalah Pegawai Karyawan PT. POS Indonesia (Persero) Bandar Lampung jalan Jl. KH. Ahmad Dahlan No. 21 Bandar Lampung yang berlangsung dari Bulan April hingga Mei 2021. Variabel bebas (X) adalah Motivasi Kerja dan Variabel terikat (Y) adalah Kinerja Pegawai. Metode pengumpulan penelitian ini adalah observasi dan angket (Questionary). sampel dalam penelitian ini adalah 29 orang. Analisis data menggunakan analisis regresi linear sederhana yaitu Uji-t. Dari hasil perhitungan uji $\mathrm{t}$ didapat nilai $\mathrm{t}_{\text {hitung }}=3.128>\mathrm{t}_{\mathrm{tabel}} 2,75$ dimana kesimpulannya adalah bahwa hipotesa yang menyatakan terdapat pengaruh antara variabel Motivasi Kerja (X) terhadap Kinerja Karyawan (Y) pada Karyawan PT. POS Indonesia (Persero) Bandar Lampung. Jadi variabel Motivasi Kerja (X) berpengaruh terhadap variabel Kinerja $(\mathrm{Y})$.
\end{abstract}

Kata kunci: Kinerja Pegawai, Motivasi Kerja, PT. Pos Indonesia (Persero)

\begin{abstract}
.
The purpose of the study was to determine whether work motivation had an effect on the performance of employees of PT. Pos Indonesia (Persero) Bandar Lampung. The object of this research is the employee of PT. POS Indonesia (Persero) Bandar Lampung Jl. KH. Ahmad Dahlan No. 21 Bandar Lampung which takes place from April to May 2021. The independent variable (X) is Work Motivation and the dependent variable (Y) is Employee Performance. The method of collecting this research is observation and questionnaire (Questionary). the sample in this study were 29 people. Data analysis used simple linear regression analysis, namely $t$-test. From the results of the calculation of the $t$ test, the value of tcount $=3.128>$ ttable 2.75 where the conclusion is that the hypothesis which states that there is an influence between the variables of Work Motivation (X) on Employee Performance (Y) on Employees of PT. POS Indonesia (Persero) Bandar Lampung. So the work motivation variable $(X)$ has an effect on the performance variable $(Y)$.
\end{abstract}

Keywords: Employee Performance, Work Motivation, PT. Pos Indonesia (Persero)

\section{PENDAHULUAN}

Peran pemerintah sebagai regulator dalam hal ini pembuatan dan penerapan kebijakan (Nirwana et al., 2017) dan sebagai aktornya (pelaksana) salah satunya dijalankan oleh Badan Usaha Milik Negara (BUMN)(Aprilinda \& Puspa, 2019). BUMN adalah sebuah badan usaha yang mempunyai peranan penting sebagai agen pembangunan (Aqmarina, 2018) dalam penyelenggaraan perekonomian nasional guna mewujudkan kesejahteraan masyarakat (Devi Yulianti, 2018).
Menurut Penjelasan Umum Undangundang Nomor 19 Tahun 2003 tentang BUMN, BUMN yang seluruh atau sebagian besar modalnya berasal dari kekayaan negara yang dipisahkan merupakan salah satu pelaku ekonomi dalam sistem perekonomian nasional (Juliani, 2018). Selain itu, BUMN ikut berperan menghasilkan barang dan/atau jasa yang diperlukan dalam rangka mewujudkan sebesar-besarnya kemakmuran masyarakat (Hartanto et al., 2021).

Hal ini menunjukkan bahwa BUMN yang memiliki peran sebagai penggerak roda 
ekonomi di Indonesia dirasakan semakin penting karena mempunyai peran strategis sebagai pelaksana pelayanan publik, penyeimbang kekuatan-kekuatan swasta besar, dan turut membantu pengembangan usaha kecil/koperasi (Ginting, 2020).

Salah satu BUMN tertua di Indonesia yang masih ada ialah PT. Pos Indonesia (Persero). Sebelum dikenal sebagai Pos Indonesia yang memiliki catatan sejarah begitu panjang, dimana Kantor Pos Indonesia pertama kali didirikan pada tahun 1746 di Batavia (Jakarta) (Azhari \& Budianto, 2021) dengan tujuan untuk lebih menjamin keamanan surat-surat penduduk (Sinambela et al., 2018).

Akan tetapi, pada saat akhir abad 20 PT. Pos Indonesia (Persero) tidak dalam posisi yang baik dalam meningkatkan volume dari setiap produk layanan yang dimiliki. Hal ini dikarenakan pada tahun 1998 hingga awal tahun 2000-an Indonesia sedang mengalami Krisis moneter yang mengguncang sendisendi ekonomi dan perpolitikan Indonesia (Priyatno, 2017). Ketidakberhasilan dalam meningkatkan jumlah volume produk pada PT. Pos Indonesia (Persero) masih berlanjut mulai dari tahun 2004 sampai tahun 2008.

PT. Pos Indonesia (Persero) mengalami masa-masa sulit bahkan hampir mengalami kebangkrutan karena mengalami fluktuasi dan cenderung menurun (Januarsyah et al., 2019). Salah satu penurunan volume produksi terjadi pada surat biasa atau pribadi yang sangat tajam diduga terkait dengan semakin sedikitnya penggunaan surat melalui pos sebagai sarana pemberi kabar/informasi, seiring dengan semakin berkembangnya teknologi informasi.

Perkembangan zaman yang semakin pesat memaksa setiap perusahaan, instansi atau organisasi untuk terus bertahan dalam persaingan global (Nasution, 2020) dan mengikuti perubahan-perubahan yang terjadi terutama dalam pengelolaan dan peningkatan mutu sumber daya manusia (Rahman, 2020). Saat ini Pos Indonesia tidak hanya melayani jasa pos dan kurir, tetapi juga jasa keuangan, ritel, dan properti, yang didukung oleh titik jaringan sebanyak lebih dari 4.000 kantor pos dan 28.000 Agen Pos yang tersebar di seluruh wilayah Indonesia (Prihatin et al., 2021). Hal ini muncul sebagai respon pemerintah setelah melihat tingginya permintaan akan pelayanan jasa (Marbun et al., 2020).

Sumber daya manusia di setiap perusahaan/badan usaha menjadi salah satu faktor penting yang perlu diperhatikan oleh perusahaan (Fernandes \& Marlius, 2018), karena Karyawan berperan aktif dalam menetapkan rencana, sistem, proses, dan tujuan yang ingin dicapai (Susan, 2019). Sumber daya manusia yang berkinerja baik akan mampu merancang dan melaksanakan semua proyek guna mencapai sasaran suatu organisasi (Muizu \& Sule, 2017). Sumber daya manusia dikatakan berkinerja baik apabila memiliki disiplin dan Produktivitas kerja yang tinggi (Aromega et al., 2019) serta dapat menyelesaikan pekerjaannya dengan tepat waktu (Ferawati, 2017).

PT. Pos Indonesia (Persero) Bandar Lampung merupakan Badan Usaha Milik Negara (BUMN) yang bergerak di bidang pengiriman parsel dan surat serta telah berubah menjadi jasa keuangan. Sejauh ini PT. Pos (Persero) Indonesia Bandar Lampung terus meningkatkan berbagai inovasi melalui pengembangan produk di layanan lainnya. Meski telah dibarengi dengan berbagai bentuk program peningkatan kinerja pegawai, seperti tracking update status kiriman dan feedback kinerja, namun kenyataannya belum sepenuhnya diimplementasikan secara optimal. Bagi karyawan, agar mau bekerja keras dan dapat menunjang kinerja yang baik dari tujuan perusahaan yang diinginkan. Tentunya perlu didukung oleh beberapa hal, diantaranya adalah motivasi kerja.

Kualitas kinerja seorang pegawai juga dipengaruhi oleh beberapa faktor, antara lain kualitas manusia itu sendiri, lingkungan organisasi bahkan motivasi kerja. Motivasi kerja dapat dipengaruhi oleh beberapa faktor, antara lain tempat kerja yang nyaman agar menghasilkan kinerja optimal (Lestary 
\& Harmon, 2017) dan merangsang karyawan agar memiliki semangat yang tinggi dalam melakukan pekerjaannya (Ardian, 2019). Jika karyawan telah memandang lingkungan kerja sebagai mendukung, sangat mempengaruhi motivasi mereka untuk bekerja, maka mereka akan mampu mengatasi tekanan yang mereka hadapi dan akan menghargai serta akan melakukan pekerjaannya sebaik mungkin (Panjaitan, 2018).

Masalah lain yang dihadapi PT. Pos Indonesia yang juga mirip dengan Bandar Lampung ini adalah sering mengeluhkan keterlambatan pengiriman barang (Chusminah et al., 2019) yang bahkan tidak sampai ke tangan penerima. Keluhan lain adalah keengganan PT. Pos untuk mengantarkan kiriman tepat waktu, sehingga penerima dan pengirim harus datang dan pergi ke kantor pos untuk memeriksa. Keluhan ini terdapat pada tabel hasil papan buletin yang diisi konsumen saat berkunjung ke Kantor Pos Indonesia (Persero) Bandar Lampung yang setiap minggunya diganti dengan keluhan lainnya.

Meskipun motivasi umumnya mengacu pada upaya yang dilakukan untuk mencapai setiap tujuan, di sini mengacu pada tujuan organisasi karena fokusnya adalah pada perilaku yang berhubungan dengan pekerjaan. Dalam meningkatkan motivasi karyawan PT. Pos Indonesia (Persero)
Bandar Lampung menawarkan gaji, tunjangan dan insentif berdasarkan keterampilan dan posisi karyawan untuk meningkatkan kinerjanya. Namun di satu sisi dewasa ini para pegawai mengalami rasa khawatir terutama rasa aman dalam bekerja, karena selain lingkungan kerja yang ada sekarang ini, penghargaan yang diberikan dari PT. Pos Indonesia (Persero) Bandar Lampung kurang dirasakan pegawai karena adanya persaingan jasa pengiriman barang (Putri et al., 2014).

Adanya pengawasan, maka kedisiplinan karyawan PT. Pos (Persero) Bandar Lampung tidak disanksikan lagi, para karyawan bekerja dengan sebaik-baiknya, hubungan kerja antar karyawan berjalan dengan sangat baik begitu juga dengan loyalitas. Namun berkenaan dengan sortir barang pengiriman (paket) ada sebagian karyawan yang kurang puas dalam bekerja sehingga produktifitas dalam bekerja juga menurun. Dalam hal ini terkesan bahwa ada Sebagian karyawan pengiriman barang kurang kreatif dan terlihat kurang memiliki rasa tanggungjawab terhadap tugastugasnya.

Dalam tabel kinerja di bawah ini memperlihatkan bahwa hasil kinerja kurir pada bulan September 2020 mengalami pertumbuhan yang baik dan sesuai dengan target berhasil antar.

Tabel 1. Hasil Kinerja Antaran Kurir Surat dan Paket PT. Pos Indonesia (Persero) Bandar Lampung Periode Bulan September 2020

\begin{tabular}{lcccc}
\hline \multicolumn{1}{c}{ Cabang } & $\begin{array}{c}\text { Jumlah } \\
\text { Kiriman } \\
\text { (Paket) }\end{array}$ & $\begin{array}{c}\text { Keterlambatan } \\
\text { Kiriman } \\
\text { (Per Bulan) }\end{array}$ & $\begin{array}{c}\text { Target } \\
\text { Keberhasilan } \\
(\%)\end{array}$ & $\begin{array}{c}\text { Keterlambatan } \\
\text { Antar } \\
(\%)\end{array}$ \\
\hline Tanjungkarang Barat & 938 & 101 & 90 & 10 \\
Plaza Pos & 1147 & 63 & 95 & 5 \\
Way Halim & 1018 & 61 & 95 & 5 \\
Antasari & 977 & 161 & 84 & 10 \\
Kedaton & 893 & 163 & 82 & 18 \\
Pahoman & 1219 & 80 & 94 & 6 \\
Kemiling & 911 & 55 & 94 & 6 \\
\hline
\end{tabular}

Sumber: PT. Pos Indonesia (Persero) Bandar Lampung. 2021

Dari tabel 1 di atas dapat dilihat bahwa hasil kinerja antaran kurir surat dan paket terhitung priode hingga bulan September menunjukkan adanya kenaikan dalam antar kiriman paket. Untuk jumlah kiriman terbesar dari Kantor Pos Cabang adalah 
Pahoman dengan jumlah kiriman paket sebanyak 1.219 paket.

Adanya pengaruh tersebut didasari oleh peraturan perusahaan yang mengatur bahwa minimal presentase berhasil antar yaitu sebesar $97 \%$ setiap bulan. Bila dibandingkan dengan sebelum ada masalah pengiriman karena adanya pesaingan antar barang, sebenarnya Paket pengiriman melalui PT.Pos Indonesia (Persero) Bandar Lampung lebih besar dari yang ada sekarang, dan bahkan volume paket $10 \mathrm{kali}$ lipat dari yang ada saat ini.

Sebagaimana disebutkan di atas bahwa antaran surat oleh petugas kurir pada PT. Pos Indonesia (Persero) Bandar Lampung masih berjalan dan hal ini masih menunjukkan adanya kinerja sekalipun dengan adanya permasalahan kelembagaan para karyawan mengalami penurunan motivasi dalam bekerja. Seharusnya adanya kinerja yang merupakan hasil dari proses pekerjaan tertentu secara terencana pada waktu dan tempat dari karyawan serta organisasi bersangkutan seperti tergambarkan pada tabel kinerja yang memperlihatkan bahwa hasil kinerja kurir pada bulan September 2020 mengalami pertumbuhan yang baik dan sesuai dengan target berhasil antar. Tetapi berdasarkan kondisi pekerjaan dan lingkungan kerja yang ada saat ini,

Beban kerja yang dilaksanakan mengalami masalah terutama dalam hal kualitas dan kuantitas kerja oleh karena waktu pelaksanaan pekerjaan menjadi permasalahan baru dengan penyebab utamanya adalah suasan dan lingkungan kerja organisasi ini yang menjadi permasalahannya sehingga waktu yang dipakai dalam penyelesaian pekerjaan menjadi permasalahan juga. Permasalahan lain yang dihadapi PT. Pos seluruh Indonesia dan ini juga berlaku di PT. Pos Bandar
Lampung dimana PT. Pos Indonesia menjadi salah satu perusahaan jasa kurir yang mencatatkan kinerja kurang baik dari pandemi virus corona ini. Sementara jasa kurir pesaing seperti J\&T Express dan JNE tetap optimistis dan menargetkan peningkatan volume hingga 2 kali lipat jelang Lebaran.

Berdasarkan uraian di atas, maka Tujuan penelitian untuk mengetahui apakah motivasi kerja berpengaruh terhadap kinerja karyawan PT. Pos Indonesia (Persero) Bandar Lampung.

\section{METODE PENELITIAN}

Metode penelitian yang digunakan dalam penelitian menggunakan metode penelitian deskritif kuntitatif. Objek penelitian ini adalah Pegawai Karyawan PT. POS Indonesia (Persero) Bandar Lampung jalan Jl. KH. Ahmad Dahlan No. 21 Bandar Lampung yang berlangsung dari Bulan April hingga Mei 2021.

Variabel bebas (X) adalah Motivasi Kerja dan Variabel terikat (Y) adalah Kinerja Pegawai. Metode pengumpulan penelitian ini adalah observasi dan angket (Questionary). sampel dalam penelitian ini adalah 20\% x 143 Karyawan dengan jumlah 29 orang. Analisis data menggunakan analisis regresi linear sederhana yaitu Uji-t.

\section{HASIL DAN PEMBAHASAN}

Perhitungan pengaruh antara variabel Motivasi Kerja (X) terhadap Kinerja (Y) pada Karyawan PT. POS Indonesia (Persero) Bandar Lampung, menggunakan hasil perhitungan melalui program SPSS For Windows 21.0 dan hasil statistik adalah sebagai berikut :

Tabel 2. Hasil Uji Regresi Linear Sederhana 
Coefficients $^{\mathrm{a}}$

\begin{tabular}{lrrrrr}
\hline \multirow{2}{*}{ Model } & \multicolumn{2}{c}{$\begin{array}{c}\text { Unstandardized } \\
\text { Coefficients }\end{array}$} & $\begin{array}{c}\text { Standardized } \\
\text { Coefficients }\end{array}$ & \multirow{2}{*}{ t } & \multirow{2}{*}{ Sig. } \\
\cline { 2 - 3 } & \multicolumn{1}{c}{ B } & \multicolumn{1}{c}{ Std. Error } & Beta & & \\
\hline 1 (Constant) & 14.596 & 2.215 & & 4.580 & .012 \\
Motivasikerja & .625 & .076 & .214 & 3.128 & .000 \\
\hline a. Dependent Variable: Vol.Penjualan & & & & &
\end{tabular}

Berdasarkan hasil uji t didapat nilai thitung $=0.128$ Apabila dibandingkan dengan ttabel pada taraf signifikan 0,05 yaitu 2,75 , maka $\mathrm{t}_{\text {hitung }}=0,128>\mathrm{t}_{\text {tabel }} 2,75$ sehingga dapat disimpulkan bahwa hipotesa yang menyatakan terdapat pengaruh antara variabel Motivasi Kerja (X) terhadap Kinerja Karyawan (Y) pada Karyawan PT.
POS Indonesia (Persero) Bandar Lampung. Jadi variabel Motivasi Kerja (X) berpengaruh terhadap variabel Kinerja (Y).

Seberapa jauh variabel Motivasi Kerja menjelaskan variabel Kinerja Karyawan dapat ditentukan berdasarkan nilai koefisien determinasi $\left(\mathrm{R}^{2}\right)$ di bawah ini.

Tabel 6. Uji Koefisien Determinasi

Model Summary

\begin{tabular}{lccrr} 
Model & R & R Square & $\begin{array}{c}\text { Adjusted R } \\
\text { Square }\end{array}$ & $\begin{array}{c}\text { Std. Error of the } \\
\text { Estimate }\end{array}$ \\
\hline 1 & $.686^{\mathrm{a}}$ & .471 & .451 & 2.511 \\
\hline a. Predictors: (Constant), Motivasikerja & & & &
\end{tabular}

Koefisien Determinasi $\mathrm{R}^{2}=0,6862=$ $0,471=0,471 \times 100=47,1 \%$. Dapat disimpulkan bahwa variabel Motivasi Kerja menjelaskan variasi perubahan terhadap variabel Kinerja Karyawan PT. POS Indonesia (Persero) Bandar Lampung sebesar $47,1 \%$, sedangkan sisanya sebesar $52,9 \%$ dijelaskan oleh faktor lain yang tidak dikaji dalam penelitian ini, oleh sebab dalam dinamika kehidupan manusia, pegawai Karyawan PT. POS Indonesia(Persero) Bandar Lampung pada saat penelitian Motivasi Kerja dan Kinerja saling mempengaruhi hal ini dibuktikan dengan nilai koefisien determinasi sebesar 47,1\% dan sisanya sebesar $52,9 \%$ dipengaruhi oleh faktor lain, dalam hal ini variabel Insentif, Disiplin, lingkungan kerja, efektifitas, kepemimpinan dan lainnya adalah variabel lain yang sebenarnya mempengaruhi pada saat penelitian ini berlangsung, hanya saja peneliti hanya melihat dan mengekspresi variable Motivasi Kerja dan Kinerja saja. Persamaan regresi antara variabel Motivasi Kerja terhadap Kinerja pegawai adalah $\mathrm{Y}=$
$14,596+0,625 \mathrm{X}$, yang artinya setiap kenaikan satu point dari pada variabel Motivasi Kerja akan diikuti oleh naiknya variabel Kinerja pada Karyawan PT. POS Indonesia Bandar Lampung sebesar 0,625 point.

\section{KESIMPULAN}

Berdasarkan hasil penelitian diperoleh kesimpulan bahwa Dari hasil perhitungan uji-t didapat nilai $t_{\text {hitung }}=3.128>\mathrm{t}_{\text {tabel }} 2,75$ dimana kesimpulannya adalah bahwa hipotesa yang menyatakan terdapat pengaruh antara variabel Motivasi Kerja (X) terhadap Kinerja Karyawan (Y) pada Karyawan PT. POS Indonesia (Persero) Bandar Lampung. Jadi variabel Motivasi Kerja (X) berpengaruh terhadap variabel Kinerja (Y).

\section{DAFTAR PUSTAKA}

Andari, R., \& Napu, D. M. (2016). Pengaruh word of mouth terhadap keputusan pembelian tiket maskapai 
penerbangan domestik di davina tour and travel gorontalo. THE Journal: Tourism and Hospitality Essentials Journal, 6(1), 1013-1022. http://www.bssaonline.org/content/95 /6/2373\%5Cnhttp://www.bssaonline.o rg/content/95/6/2373.short\%0Ahttp:// www.bssaonline.org/cgi/doi/10.1785/ 0120110286\%0Ahttp://gji.oxfordjour nals.org/cgi/doi/10.1093/gji/ggv142\% 0Ahttp://link.springer.com/10.1007/s 00024-01

Aprilinda, Y., \& Puspa, A. K. (2019). Metode Audit Tata Kelola Teknologi Informasi Pada Badan Usaha Milik Negara. Expert - Jurnal Management Sistem Informasi Dan Teknologi, 9(1), $8-12$.

Aqmarina, R. (2018). MONOPOLI OLEH BUMN DALAM PRESPEKTIF ASEAN ECONOMIC COMMUNITY (AEC). E-Jurnal: Spirit Pro Patria, $4(2), 170-179$.

Ardian, N. (2019). Pengaruh insentif berbasis kinerja, motivasi kerja, dan kemampuan kerja terhadap prestasi kerja pegawai UNPAB. Jurnal Kajian Ekonomi Dan Kebijakan Publik, 4(2), 119-132.

Aromega, T. N., Kojo, C., \& Lengkong, V. P. K. (2019). Pengaruh Kompensasi Dan Disiplin Kerja Terhadap Kinerja Karyawan Di Yuta Hotel Manado. Jurnal EMBA: Jurnal Riset Ekonomi, Manajemen, Bisnis Dan Akuntansi, $7(1)$, 741-750. https://doi.org/10.35794/emba.v7i1.2 2531

Azhari, A. L., \& Budianto. (2021). Pengawasan Internal Untuk Pencegahan Kecurangan Keuangan Di Kantor Pos Meulaboh 23600. Jurnal Indonesia Sosial Sains, 2(1), 18261837.

Chusminah, C., Haryati, A., \& Nelfianti, F. (2019). Efektivitas Pengelolaan Persediaan Barang Dengan Sistem Safety Stock Pada PT X di Jakarta. Jurnal Economic Resource, 2(1), 1-
13.

https://doi.org/10.33096/jer.v2i1.230

Devi Yulianti. (2018). Implementasi Program Kemitraan Dalam Corporate Social Responsibility (CSR) Melalui Pemberdayaan Masyarakat Untuk Mewujudkan Pembangunan Kesejahteraan. Sosiologi: Jurnal Ilmiah Kajian Ilmu Sosial Dan Budaya, 20(1), 11-21.

Ferawati, A. (2017). Pengaruh Lingkungan Kerja Dan Disiplin Kerja Terhadap Kinerja Karyawan. Jurnal Agora, $5(1)$.

http://eprints.uny.ac.id/41801/1/Adity aNurPratama_12808144059.pdf

Fernandes, Y. D., \& Marlius, D. (2018). Peranan Customer Service Dalam Meningkatkan Pelayanan Kepada Nasabah Pada Pt. Bank Pembangunan Daerah Sumatera Barat Cabang Utama Padang. 1-12. https://doi.org/10.31227/osf.io/wrh3p

Ginting, Y. P. (2020). Holding Bumn Memerlukan Adanya Standar Prosedur Operasi Dalam Mencapai Aspek Tata Kelola Perusahaan Yang Baik. Majalah Hukum Nasional, 50(1), 1-18. https://doi.org/10.33331/mhn.v50i1.5 3

Hartanto, G. S., Kania, D., \& Afriana, A. (2021). Aktualisasi Mitigasi Risiko Bisnis Berdasarkan Prinsip Fiduciary Duty dan Business Judgment Rule. Jurnal Sains Sosio Humaniora, 5(2), 1191-1202.

Januarsyah, I., Jubi, Inrawan, A., \& Putri, D. E. (2019). Pengaruh Biaya Produksi Dan Biaya Pemasaran Terhadap Laba Perusahaan Pada PT PP London Sumatera Indonesia, Tbk. Jurnal Akuntansi, 5(1), 32-39.

Juliani, H. (2018). Aspek Yuridis Transformasi Hukum Keuangan Publik Ke Keuangan Privat Terhadap Pengelolaan Kekayaan Negara yang Dipisahkan Pada BUMN. Administrative Law \& Governance 
Journal, 1(1), 25-43.

Lestary, L., \& Harmon. (2017). Pengaruh Lingkungan Kerja Terhadap Kinerja Karyawan Lyta. Jurnal Riset Bisnis Dan Investasi, 3(2), 94-103. https://doi.org/10.35697/jrbi.v3i1.545

Muizu, W. O. Z., \& Sule, E. T. (2017). Manajer Dan Perangkat Manajemen Baru. NASPA Journal, 42(4), 1. (PDF) Jurnal Manajemen Kantor $1 \% 7 \mathrm{C}$ Feira Dewi Fatmasari - Academia.edu Nasution, L. (2020). Efektifitas HKI Sebagai Pelindung Industri Kreatif dan UMKM di Tengah Pandemi Covid-19. ADALAH Buletin Hukum \& Keadilan, volume 4(1), 238-250.

Nirwana, D. C., Muhammadiah, M., \& Hasanuddin, M. (2017). Peran Pemerintah Dalam Pembinaan Usaha Kecil Menengah Di Kabupaten Enrekang. Kolaborasi: Jurnal Administrasi Publik, 3(1), 1-14. https://doi.org/10.26618/kjap.v3i1.89 0

Panjaitan, M. (2018). Peran keterlibatan dan partisipasi karyawan terhadap kinerja karyawan. Jurnal Manajemen, 4(1), $52-60$.

Paulus, J. J. ., Bessie, J. L. ., \& Kasim, A. (2015). Pengaruh Word of Mouth (WOM) Terhadap Keputusan Berkunjung Wisatawan Di Kampung Adat Boti Kabupaten TTS. Journal of Management: Small and Medium Enterprises (SMEs), 1(1), 37-61.

Priyatno, D. (2017). Kerja Sama IndonesiaUNCTAD dalam Implementasi Competition Law and Policy di Indonesia Periode 2004-2007. Journal of International Relations, 3(1), 115122.

Putri, S. N., Kusmaningrum, \& Arijanto, S. (2014). Pengukuran Brand Equity Jasa Pengiriman di PT. Pos Indonesia (Persero). Reka Integra, 2(3), 360371.

Rahman, Y. A. (2020). Manajemen Sumber Daya Manusia. Tsaqofah: Jurnal Pendidikan Islam, 4(2), 1-23.
Sinambela, Z. S., Ginting, G. L., Ginting, P., \& Waruwu, F. T. (2018). Perancangan Aplikasi Kode Pos Indonesia Berbasis Mobile Dengan Menerapakan Algoritma Zhu-Takaoka. KOMIK (Konferensi Nasional Teknologi Informasi Dan Komputer), 2(1), 390396.

https://doi.org/10.30865/komik.v2i1.9 64

Susan, E. (2019). Manajemen Sumber Daya Manusia. Adaara: Jurnal Manajemen Pendidikan, 9(2), 952-962. 